\title{
First Report of Fusarium proliferatum Inciting Wilt of Rumex acetosa L. in Maharashtra, India
}

\author{
Udhav Narba Bhale ${ }^{1 *}$, Vaishali Sidram Chatage ${ }^{1}$ and Mallama Gurunath Ambuse ${ }^{2}$
}

${ }^{1}$ Research laboratory, Department of Botany, Arts, Science and Commerce College Naldurg, Dist. Osmanabad -413602 Maharashtra State, India ${ }^{2}$ Department of Botany, Shrikrishna College Gunjoti Tq. Omerga Dist Osmanabad- 413613 Maharashtra State, India.

\begin{abstract}
Wilt of sorrel is caused by Fusarium proliferatum. Symptoms included yellow discolorations and wilting of lower leaves. Internal transcribed spacer (ITS) region of rDNA was amplified using the ITS1 and ITS4 primers and resulted in a $569 \mathrm{bp}$ which was utilized for identification of this fungus. This is the first report of wilt of sorrel from Maharashtra.
\end{abstract}

Keywords: Rumex acetosa; Fusarium proliferatum; Pathogenicity; Sequencing.

Rumex acetosa L. (sorrel) belongs to family Polygonaceae. It is an indigenous English plant, common, too in the greater part of Europe, in almost all soils and situations. The medicinal action of sorrel is refrigerant and diuretic, febrile disorders and in scurvy. In India it is cultivated as a medicinal and vegetable throughout the year. Both the root and the seed were formerly esteemed for their astringent properties, and were employed to stem haemorrhage [1]. During October 2009 to January 2011 an extensive surveys was conducted in sorrel growing areas of Marathwada region of Maharashtra, India where diseased plants were found with yellow discoloration of the vascular tissue in stems, wilting of the lower leaves \& root rot (Figure1). Roots from wilted plants were collected and cut into small pieces $(2 \mathrm{~mm})$ and then surface sterilized with mercuric chloride $\left(1 \% \mathrm{HgCl}_{2}\right)$ for $1 \mathrm{~min}$. The pieces were then washed with sterilized distilled water three times, blotted dry and plated on potato dextrose agar (PDA) medium and incubated at $27 \pm 2^{\circ} \mathrm{C}$ in BOD incubator. On PDA medium, Fusarium species with catenate microconidia and macroconidia borne on polyphialides was consistently isolated from the infected roots. Pathogenicity tests were conducted, using six healthy sorrel plants grown in the glasshouse. Two plants and a control were used for each of two replications. For each treated plants were sprayed with $5 \mathrm{ml}$ conidia suspension (ca. $1 \times 10^{5}$ conidia/ml) in sterilized water (SDW) and maintained in a humid growth chamber for $24 \mathrm{~h}$ in room temperature. Five days after inoculation, white mycelial roots were infected and in control remained symptomless. The fungus was reisolated \& was identical as Fusarium species. The fungal culture is deposited at CODON Life Sciences, Goa and Research laboratory, Department of Botany Arts, Science \& Commerce College Naldurg Dist Osmanbad, Maharashtra State, India with Accession No.HQ332533.

Thirty isolates were identified as Fusarium proliferatum (Matsushima) Nirenberg [2,3].Cultural colonies were started from
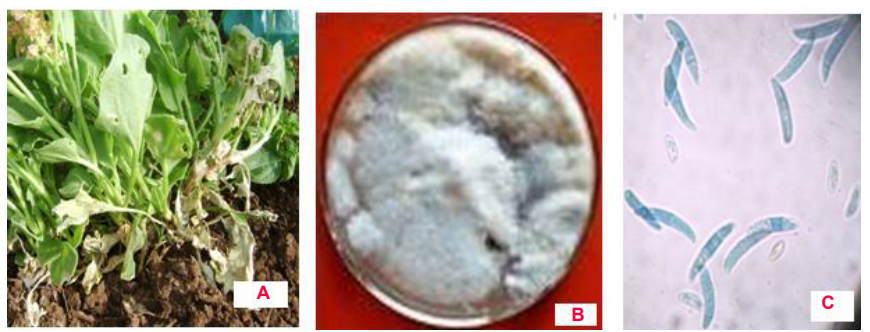

Figure 1: Wilt of Rumex acetosa: A-Infected plant, B- Colony of Fusarium proliferatum, C-Conidia. single conidium and grown on $\mathrm{PDA}$ at $27 \pm 2^{\circ} \mathrm{C}$ under fluorescent lights providing $12 \mathrm{hrs}$ light period. The abundant aerial mycelium initially was white and later became purple violet. Colonies were fast growing, hyphae were septate and hyaline. Conidiophores were short, simple and branched. Microconidia were abundant and produced on mono and polyphialids, single celled, oval to club shaped size $7.0-22.5 \times 3.5 \mu \mathrm{m}$. Macroconidia were slightly sickle shaped to straight, with 2-5 septa and measured 43-65×3.3-5.0 $\mu \mathrm{m}$. Chlamydospores were absent (Figure 1).

The internal transcribed spacer (ITS) region of rDNA from the original isolate used for inoculation \& re-isolated culture recovered from roots in the pathogenicity studies, were amplified with polymerase chain reaction (PCR) using primer ITS1 and ITS4 [4]. PCR amplicons of approximately $569 \mathrm{bp}$ were obtained. Sequences of amplicons were identical and the sequence was submitted to GenBank (Accession No.JQ322969). The DNA sequences were 99\% identical to telomorph of G. intermedia strains (EU364856.7; EU364846.5; EU364845.5).

Fusarium proliferatum is known to cause diseases like Fusarium crown and root rot of asparagus [5], leaf spot of cymbidium [6], and rot of garlic bulb [7].To our knowledge this is the first report of Fusarium proliferatum causing wilting of sorrel in Maharashtra State, India.

Our further investigation will made to evaluate the management practices for controlling this disease.

\section{Acknowledgement}

Authors are thankful to UGC, New Delhi [F.No.38-19/2009 (SR)] for the financial assistance of major research project.

\section{References}

1. Cooke CIET (1903) Flora of Presidency of Bombay, Vol 1. Published under the Authority of Secretary of State for Council.

2. Nelson PE, Tossoun TA, Marassas WFO (1983) Fusarium species: An illustrated manual for identification, Pennsylvania, USA: Penn State University Press.

*Corresponding author: Dr. Udhav Narba Bhale, Department of Botany, Arts, Science and Commerce College Naldurg, Dist. Osmanabad- 413602 , Maharashtra State, India, Tel: 09890742997; Fax-02471-246042; E-mail: unbhale@rediffmail.com

Received January 16, 2012; Accepted February 29, 2012; Published March 02 2012

Citation: Bhale UN, Chatage VS, Ambuse MG (2012) First Report of Fusarium proliferatum Inciting Wilt of Rumex acetosa L. in Maharashtra, India. J Plant Pathol Microbiol 3:116. doi:10.4172/2157-7471.1000116

Copyright: @ 2012 Bhale UN, et al. This is an open-access article distributed under the terms of the Creative Commons Attribution License, which permits unrestricted use, distribution, and reproduction in any medium, provided the original author and source are credited. 
Citation: Bhale UN, Chatage VS, Ambuse MG (2012) First Report of Fusarium proliferatum Inciting Wilt of Rumex acetosa L. in Maharashtra, India J Plant Pathol Microbiol 3:116. doi:10.4172/2157-7471.1000116

Page 2 of 2

3. Nirenberg H, O'Donnel K (1998) New Fusarium species and combinations within the Gibberella fujikuroi species complex. Mycologia 90: 434-458.

4. White TJ, Bruns T, Lee S, Taylor J (1990) Amplification and direct sequencing of fungal risbosomal RNA genes for phylogenitics. In: Innis MA, Gelfand DH Sninsky JJ, White TJ, eds. PCR Protocol. A guide to methods and Applications, New York, NY, USA: Academic Press, 315-322.
5. Elmer WH (1990) Fusarium proliferatum as causal agent in Fusarium crown and root rot of asparagus. Plant Disease 74: 938.

6. Gerlach W, Nirenberg H (1982) The genus Fusarium: A pictorial Atlas. Mitt Biol Bundescanst Land Forstwirtsch Berl Dahlem 209: 301-344.

7. Dugan FM, Hellier BC, Lupien SL (2003) First report of Fusarium proliferatum causing rot of garlic bulbs in North America. Plant Pathol 52: 426. 